\title{
PEMAHAMAN IDENTITAS MORAL DALAM MENINGKATKAN KEMAMPUAN PENGAMBILAN KEPUTUSAN ETIS BAGI PARA PESERTA DIDIK PENDIDIKAN AGAMA KRISTEN
}

\author{
Amos Winarto Oei \\ Sekolah Tinggi Teologi Aletheia, Lawang
}

\begin{abstract}
This article examines whether appealing to learners' moral identity makes a significant contribution to their ethical decision making. Moral identity theory and experiment in moral psychology will be used as a source to be reckoned with in improving ethical decision making. This is to avoid excessive emphasis on emotions, environment and knowledge of the rules which did have an impact on one's ethical decision making.

The approach used in this article is the quantitative approach. The result showed that the understanding of moral identity can act as an element to boost the ability of ethical decision making. This suggests that religious education which appeals to the learner's moral identity can help them to make better ethical decision when complementing the emotional, the environment and the rule-based knowledge approaches. Thus, it is expected that the learners can have good moral character in the future. This moral identity appeal should be widely adopted as a common practice in religious education class.
\end{abstract}

KEYWORDS: moral identity, ethical decision, understanding, cognitive development, religious education.

ABSTRAK: Artikel ini meneliti apakah dengan memberikan pemahaman identitas moral kepada para peserta didik akan memberikan dampak untuk meningkatkan kemampuan pengambilan keputusan etis mereka. Teori 
identitas moral dan eksperimen dalam psikologi moral akan digunakan sebagai sumber yang patut dipertimbangkan manfaatnya untuk meningkatkan kemampuan pengambilan keputusan etis. Hal ini untuk menghindari penekanan yang berlebihan terhadap emosi, lingkungan dan pengetahuan tentang aturan yang memang mempunyai dampak terhadap pengambilan keputusan etis seseorang.

Pendekatan yang digunakan dalam artikel ini adalah pendekatan kuantitatif. Hasil penelitian menunjukkan bahwa pemahaman identitas moral dapat bertindak sebagai unsur yang meningkatkan kemampuan pengambilan keputusan etis. Ini menganjurkan bahwa pendidikan agama yang mempertimbangkan identitas moral para peserta didiknya dapat menolong mereka untuk membuat keputusan etis dengan lebih baik dalam melengkapi pendekatan emosi, lingkungan dan pengetahuan yang berdasarkan aturan. Dengan demikian, diharapkan mereka dapat memiliki akhlak dan karakter yang semakin bermoral juga di masa mendatang. Pertimbangan identitas moral demikian seharusnya digunakan secara luas sebagai praktek umum dalam kelas pendidikan agama.

KATA KUNCI: identitas moral, keputusan etis, pemahaman, perkembangan kognitif, pendidikan agama.

\section{Pendahuluan}

Selama bertahun-tahun, model perkembangan kognitif - yang pada mulanya diusulkan oleh Kohlberg${ }^{1}$ dan kemudian dikembangkan oleh Rest

\footnotetext{
L. Kohlberg, "Stage and Sequence: The Cognitive Developmental Approach to Socialization," dalam A. Goslin (Ed.), Handbook of Socialization Theory and Research (Chicago: Rand McNally, 1969), 347-480.
} 
dan teman-temannya ${ }^{2}$ - seringkali dipakai untuk menjelaskan dasar seseorang dalam mengambil sebuah keputusan etis. Ide utama dari modelmodel perkembangan kognitif tersebut adalah "moral reasoning" atau "moral development" di mana seseorang menggunakan logika untuk menentukan perbedaan yang benar dan yang salah.

Namun penelitian-penelitian terakhir menunjukkan bahwa meskipun seseorang secara logis mengakui bahwa sesuatu itu salah, belum tentu orang tersebut akan mengambil keputusan moral sesuai dengan logikanya (misal, Blasi, ${ }^{3}$ Hoffman, ${ }^{4}$ Bergman, ${ }^{5}$ dan Walker 6 ). Hal ini dapat terjadi karena ada faktor-faktor lain yang memberi pengaruh dalam seseorang untuk mengambil keputusan etis. Berbagai ahli psikolog telah berusaha menjelaskan faktor-faktor lain yang berperan dalam seseorang mengambil keputusan etis selain logikanya. Misalnya, ada yang berpendapat bahwa emosi (Eisenberg ${ }^{7}$ dan Hoffman $^{8}$ ) dan intuisi (Haidt ${ }^{9}$ ) memainkan peranan yang lebih besar dalam tingkah laku moral sehari-hari seseorang daripada logikanya.

Artikel ini ditulis berdasarkan sebuah penelitian yang hasilnya menunjukkan adanya faktor selain logika, emosi dan intuisi di dalam

2 J. R. Rest, D. Narvaez, M. Bebeau, dan S. Thoma, “A Neo-Kohlbergian Approach: The DIT and Schema Theory," Educational Psychology Review 11, no. 4 (1999): 291-324.

3 A. Blasi, "Moral Cognition and Moral Action: A Theoretical Perspective," Developmental Review 3 (1983): 178-210.

4 M.L. Hoffman, Empathy and Moral Development: Implications for Caring and Justice (New York: Cambridge University Press, 2000).

5 R. Bergman, “Identity as Motivation: Toward a Theory of the Moral Self," dalam D. K. Lapsley and D. Narvaez (Eds.), Moral Development, Self, and Identity (Mahwah, NJ: Erlbaum, 2004), 21-46.

6 L.J. Walker, "Gus in the Gap: Bridging the Judgment-action Gap in Moral Functioning," dalam Lapsley and Narvaez (Eds.), Moral Development, Self, and Identity, 21-46.

$7 \quad$ N. Eisenberg, Altruistic Emotion, Cognition, and Behavior (Hillsdale, NJ: Erlbaum, 1986).

8 Hoffman, Empathy and Moral Development: Implications for Caring and Justice.

9 J. Haidt, "The Emotional Dog and Its Rational Tail: A Social Intuitionist Approach to Moral Judgment," Psychological Review 108, no. 4 (2001): 814-34. 
motivasi dan tingkah laku moral seseorang. Faktor tersebut dikenal dengan istilah "identitas moral." Tanpa adanya identitas moral, seseorang dapat terjebak untuk sekadar mengandalkan emosi, pengetahuan atau lingkungan dalam mengambil keputusan etisnya.

Manusia bukanlah robot dan karena itu mempunyai emosi. Dalam penelitian yang dilakukan oleh Huebner, Dwyer, dan Hauser, ${ }^{10}$ mereka menyimpulkan bahwa walaupun tidak ada bukti yang mendukung bahwa konsep moral itu terjadi atau ada karena emosi manusia, emosi memiliki peran yang tidak dapat diabaikan dalam memovitasi seseorang untuk bertindak moral. Implikasi dari penelitan tadi adalah bahwa jika seseorang hanya bertindak moral berdasarkan emosi, misalnya karena sedang suka atau senang, maka ketika sedang tidak suka atau tidak senang, tindakan moral itu akan berhenti.

Demikian juga memang sudah diyakini dari dulu bahwa ada hubungan yang tidak boleh diabaikan antara perkembangan intelektual dan perkembangan moral seseorang. Secara khusus, transmisi nilai-nilai moral dalam pendidikan intelektual adalah menjadi tanggung jawab langsung lembaga-lembaga pendidikan, seperti sekolah dan universitas. ${ }^{11}$ Merekalah yang bertanggung jawab untuk mengembangkan secara intelektual nilainilai moral para anak didiknya. Walaupun demikian, pada prakteknya belum tentu semakin tinggi intelek seseorang, orang itu akan semakin banyak dapat berbuat etis. Pencuri bukanlah orang bodoh, bahkan mungkin lebih pintar daripada polisi. Namun intelek yang tinggi tidaklah membuat seorang pencuri berhenti untuk mencuri. Malah yang sebaliknya bisa terjadi, pencuri itu akan menggunakan inteleknya untuk mencuri dengan lebih

\footnotetext{
10 Bryce Huebner, Susan Dwyer, dan Marc Hauser, "The Role of Emotion in Moral Psychology," Trends in Cognitive Sciences 13, no. 1 (2009): 1-6.

11 J.W. Maddock, "Morality and Individual Development: A Basis for Value Education," The Family Coordinator 21 (1972): 291-302.
} 
canggih, lebih hati-hati dan lebih tidak mudah dilacak.

Akhirnya, tanpa identitas moral yang jelas, seseorang dapat hanya ikut-ikutan dengan yang dilakukan oleh kebanyakan orang di sekitarnya. Bahkan jika pengaruh lingkungan ini begitu kuatnya, maka tidak heran Plato sampai pernah berkata bahwa jika seseorang dapat bertindak berbeda dari lingkungan ia berada, maka ia sedang mengalami suatu mukjizat: "[Y]ou may be sure that, in the present state of society, any character that escapes and comes to good can only have been saved by some miraculous interposition."12 Dengan kata lain, kebanyakan orang akan bertindak moral berdasarkan tindakan orang lain atau kelompok di mana orang itu berada. Bisa jadi sesuatu yang tidak bermoral akan dilakukan karena lingkungan di mana orang itu berada tidak memandang tindakan tersebut bermasalah.

\section{Identitas Moral: Teori dan Asumsi}

Walaupun masih belum ada konsensus bersama di antara para ahli tentang definisi "identitas moral," peninjauan pustaka menunjukkan bahwa ada dua sudut pandang utama terkait dengan identitas moral. Pertama adalah sudut pandang karakter dan kedua adalah sudut pandang kognitifsosial.

Identitas moral dari sudut pandang karakter seseorang dijelaskan oleh Augusto Blasi. Ia memperkenalkan teori "Self-Model" untuk memberikan jawaban terhadap soal tingkah laku moral yang di luar kebiasaan, seperti ketika seseorang menunjukkan sebuah komitmen untuk terus-menerus bertindak sesuai keyakinan moral yang dimilikinya. ${ }^{13}$ Pada tahun 2005 Blasi mengembangkan teorinya ini lebih lanjut dengan

\footnotetext{
12 Plato, Republic, terj. F. M.Cornford (New York: Oxford University Press, 1966), 200.

13 A. Blasi, "Moral Cognition and Moral Action: A Theoretical Perspective," 178-210 dan "Moral Identity: Its Role in Moral Functioning" dalam W. M. Kurtines dan J.L. Gewirtz (Eds.), Morality, Moral Behavior, and Moral Development (New York: John Wiley \& Sons, 1984), 128-39.
} 
memberikan tiga syarat bagi seseorang untuk membangun identitas moralnya, yaitu tekad, integritas dan hasrat moral. ${ }^{14}$ Baginya, tekad dan integritas bersifat netral secara moral dan yang paling penting dari tiga syarat itu adalah hasrat moral. Semakin kuat seseorang itu mempunyai hasrat moral (seperti kejujuran, belas kasihan, dan keadilan), semakin kuat identitas moral orang itu yang akan berdampak pada tindakan moral yang diambilnya.

Identitas moral dari sudut pandang kognitif-sosial muncul karena sudut pandang karakter memiliki keterbatasan, yang menurut Hart adalah cenderung untuk mengabaikan latar belakang sosial seseorang dan terlalu menyederhanakan kekompleksan kehidupan moral seseorang. ${ }^{15}$ Dari sudut pandang kognitif-sosial, identitas moral adalah suatu skema-diri yang terorganisasi di sekitar sejumlah sifat moral. Mengembangkan teorik Kihlstrom dan Klein,16 Aquino dan Reed berpendapat bahwa sifat-sifat moral demikian adalah suatu gambar mental yang jelas dari apa yang seorang bermoral cenderung pikirkan, rasakan, dan lakukan. ${ }^{17}$

Lebih lanjut, dengan memperhatikan juga teori Erikson tentang sebuah identitas otentik yang berakar pada jati diri seseorang dan mencakup melakukan sesuatu yang tidak bertentangan dengan jati diri tersebut, ${ }^{18}$ Aquino dan Reed meyakini bahwa identitas moral memiliki aspek pribadi

\footnotetext{
14 A. Blasi, "Moral Character: A Psychological Approach," dalam D. K. Lapsley dan F. C. Power (Eds.), Character Psychology and Character Education (Notre Dame, IN: University of Notre Dame Press, 2005), 67-100.

15 D. Hart, "The Development of Moral Identity" dalam G. Carlo dan C. P. Edwards (Eds.), Nebraska Symposium on Motivation: Moral Development through the Lifespan: Theory, Research, and Application 51 (Lincoln: University of Nebraska Press, 2005), 165-96.

16 J. F. Kihlstrom dan S.B. Klein, “The Self as a Knowledge Structure," dalam R. S. Wyer, Jr. dan T. K. Srull (Eds.), Handbook of Social Cognition (Hillsdale, NJ: Lawrence Erlbaum Associates, Inc, 1994), 153-208.

17 K. Aquino dan A. Reed, "The Self-importance of Moral Identity," Journal of Personality and Social Psychology 83, no. 6 (2002): 1423-40.

18 E. H. Erikson, Insight and Responsibility (New York: Norton, 1964).
} 
dan aspek publik. ${ }^{19}$ Aspek publik dari identitas moral ini sudah pernah dikaji secara ilmiah oleh Hart, Atkins dan Ford. ${ }^{20}$ Implikasinya adalah bahwa representasi kognitif dari identitas moral seseorang yang berada di dalam memorinya seringkali diproyeksikan secara simbolis kepada orang lain melalui tindakan orang tersebut di dalam dunia. Aspek pribadi dari identitas moral itu dikenal dengan nama internalisasi dan aspek publiknya sebagai simbolisasi.

Teori yang dipakai dalam artikel ini menggabungkan dua sudut pandang yang ada dari identitas moral tersebut. Kedua sudut pandang tersebut sebenarnya saling melengkapi. Sudut pandang karakter menolong seseorang untuk memahami tindakan bermoral dari para tokoh bermoral seperti Ibu Theresa di mana identitas moralnya menempati tempat utama dalam skema dirinya. Sedangkan sudut pandang kognitif sosial cocok untuk memahami tindakan sehari-hari seseorang di mana identitas moralnya dapat timbul dan tenggelam. Bersama-sama, penekanan pada identitas moral dan contoh-contoh empiris saling melengkapi yang diberikan oleh keduanya, mengindikasikan bahwa kedua sudut pandang ini dapat diintegrasikan dengan penuh arti.

Salah satu cara untuk mengintegrasikan sudut pandang karakter dan sudut pandang kognitif-sosial adalah dengan membawa seseorang mengutamakan identitas moralnya ketika berhadapan dengan situasi yang menuntutnya mengambil keputusan etis. Khususnya, identitas moral bukan hanya pada keinginan di level pertama melainkan juga keinginan di level kedua (yaitu keinginan tentang keinginan seseorang).

19 K. Aquino dan A. Reed, “The Self-importance of Moral Identity," 1423-40.

20 D. Hart, R. Atkins, dan D. Ford, "Urban American as a Context for the Development of Moral Identity in Adolescence," Journal of Social Issues 54 (1998): 513-30. 
Menurut Blasi tingkah laku moral adalah hasil kemauan sendiri seseorang. ${ }^{21}$ Maksudnya tingkah laku itu adalah hasil dari kesadaran seseorang tentang keinginan moral di level pertama (misal, belas kasihan dan kebaikan hati). Dari sudut pandang karakter, mereka yang selalu bertindak konsisten dengan keinginan moral di level pertama itu, melakukan sesuatu yang bermoral adalah karena menjadi seseorang yang bermoral menempati tempat tertinggi dalam sebuah hierarki sejumlah keinginan di level kedua. Sedangkan dari sudut pandang kognitif-sosial, keinginan moral di level pertama tersebut hanyalah salah satu dari banyak keinginan yang terkait dengan konsep diri seseorang dan kebutuhan untuk menjadi konsisten dengan diri sendiri. Susunan hierarki dari keinginankeinginan tersebut dapat dipengaruhi oleh faktor-faktor situasional. Misalnya, kehadiran sebuah insentif finansial untuk berhasil dalam suatu situasi akademis mungkin meningkatkan dapat dimunculkannya aspek orientasi untuk berhasil pada sebuah skema diri yang dimiliki oleh seseorang dan sebagai akibat akan menurunkan dapat dimunculkannya identitas moral pada diri orang tersebut (dan keinginan-keinginan moral di level pertama yang berhubungan dengan identitas moral tersebut).

Jika faktor-faktor situasional memang dapat memunculkan aspekaspek tertentu dari skema diri seseorang yang berbeda dari identitas moralnya, sehingga juga memunculkan keinginan level pertama yang berkaitan dengan itu yang mungkin tidak bermuatan moral (misal, seseorang berusaha berhasil meski harus mengorbankan orang lain), maka keinginan-keinginan yang berhubungan dengan aspek yang paling dapat dimunculkan dari skema diri seseorang akan menentukan tingkah lakunya meski refleksi yang sadar, sengaja dan diusahakan tidaklah hadir. Sebagai tambahan, bahkan jika seseorang ternyata terlibat dalam refleksi yang sadar

21 A. Blasi, "Moral Character: A Psychological Approach," 90. 
itu, situasi dan kondisi yang meningkatkan dapat dimunculkannya aspek tertentu dari skema diri seseorang dapat mengurangi kemungkinan dimensi moral dari sebuah tingkah laku yang ada untuk menjadi sebuah pertimbangan.

Berdasarkan kerangka teori di atas, konsep penelitian yang dipakai di sini berasumsi bahwa konsistensi tingkah laku yang berhubungan dengan identitas moral dapat terjadi jika dan hanya jika (1) keinginan moral di level pertama seseorang adalah dapat diakses secara berkesinambungan dan karenanya selalu cenderung dialami sebagai bagian dari diri orang itu sendiri terlepas dari segala faktor situasi yang ada, dan (2) Keinginan orang tersebut untuk menjadi orang yang bermoral di level yang kedua menempati tempat tertinggi di antara sejumlah keinginan-keinginan lain di level yang sama.

\section{Metode Penelitian}

Metode penelitian dalam artikel ini menggunakan pendekatan kuantitatif. Berdasarkan tingkat kejelasannya, pendekatan kuantitatif dapat dibagi menjadi tiga kategori. ${ }^{22}$ Pertama adalah penelitian deskriptif di mana penelitian yang dilakukan bertujuan untuk mengetahui nilai variabel mandiri, baik satu variabel atau lebih (independen) tanpa membuat perbandingan, atau menghubungkan dengan variabel yang lain. Kedua adalah penelitian komparatif yang bersifat membandingkan. Di sini variabelnya masih sama dengan variabel mandiri tetapi untuk sampel yang lebih dari satu, atau dalam waktu yang berbeda. Ketiga adalah penelitian asosiatif yang bertujuan untuk mengetahui pengaruh ataupun juga hubungan antara dua variabel atau lebih. Penelitian ini merupakan

22 Sugiyono, Metode Penelitian Kuantitatif, Kualitatif dan R \& D (Bandung: Penerbit Alfabeta, 2006), 39-41. 
gabungan antara penelitian komparatif dan asosiatif yang bertujuan membangun suatu teori yang berfungsi untuk menjelaskan suatu gejala.

Sampel yang digunakan dalam penelitian ini adalah sesuai dengan rekomendasi Arikunto yaitu menjadikan semua anggota populasi yang berjumlah kurang dari 100 sebagai sampel. ${ }^{23}$ Jika jumlah populasinya sangat besar dapat diambil antara $10-15 \%$ atau $20-55 \%$ atau lebih tergantung sedikit banyaknya dari kemampuan peneliti dilihat dari waktu, tenaga dan dana; sempit luasnya wilayah pengamatan dari setiap subyek, karena hal ini menyangkut banyak sedikitnya dana; dan, besar kecilnya risiko yang ditanggung oleh peneliti untuk peneliti yang risikonya besar, tentu saja jika sampelnya besar hasilnya akan lebih baik. Penelitian ini menggunakan 100\% sampel dari populasi karena jumlah seluruh populasi yang diteliti berjumlah kurang dari 100 orang.

Sugiyono juga memberikan dua macam teknik pengambilan sampel: probability sampling dan non-probability sampling. ${ }^{24}$ Probability sampling memberikan peluang sama bagi setiap anggota populasi untuk dipilih menjadi anggota sampel sedangkan non-probability sampling tidaklah demikian. Penelitian ini akan menggunakan probability sampling dengan teknik Simple Random Sampling karena anggota populasi yang ada bersifat homogen yaitu beragama Kristen. Ada dua variabel yang akan diteliti. Pertama adalah variabel independen yaitu pemahaman identitas moral peserta didik. Kedua adalah variabel dependen yaitu kemampuan pengambilan keputusan etis yang dilakukan oleh peserta didik. Identitas moral yang dimaksud di sini adalah hasrat moral yang dimiliki oleh para peserta didik sedangkan keputusan etis adalah hasil ketetapan yang diambil tanpa paksaan oleh peserta didik terkait dengan sifat moral.

23 Suharsimi Arikunto, Metodologi Penelitian (Yogyakarta: Bina Aksara, 2006).

24 Sugiyono, Metode Penelitian Kuantitatif, Kualitatif dan R E D, 89-102. 
Cara yang digunakan untuk mengumpulkan data dalam penelitian ini adalah kuesioner atau angket. Angket yang digunakan berupa seperangkat pertanyaan atau pernyataan tertulis kepada responden untuk dijawab dan digunakan untuk memperoleh informasi dari responden terkait dengan pribadinya atau hal lain yang ia pahami. ${ }^{25}$ Kuesioner atau angket yang digunakan dalam penelitian ini adalah jenis kuesioner atau angket langsung yang tertutup karena responden hanya tinggal memberikan angka pada jawaban yang dianggap tepat.

Kelebihan metode angket adalah menghemat waktu, maksudnya dengan waktu yang singkat dapat memperoleh data, menghemat biaya karena tidak memerlukan banyak peralatan dan menghemat tenaga. Kekurangannya adalah ada kemungkinan dalam memberikan jawaban atas pertanyaan responden tidak jujur, dan apabila pertanyaan kurang jelas dapat mengakibatkan jawaban bermacam-macam.

Berdasarkan Aquino dan kawan-kawan,26 penelitian ini menggunakan sejumlah angket terintegrasi yang akan didistribusikan selama satu semester. Para peserta didik yang mengambil mata kuliah agama Kristen akan terbagi menjadi dua kelas. Di sebuah kelas mereka berulang kali melakukan refleksi atas identitas moral mereka dan selanjutnya diuji dampak dari prosedur ini terhadap pengambilan keputusan etis yang mereka lakukan. Hasil itu akan dikontraskan dengan para peserta didik di kelas lain yang menjalani prosedur yang sama, hanya saja tanpa melakukan refleksi atas identitas moral mereka.

Rancangan penelitian yang digunakan adalah bersifat true experimental design. Menurut Sugiyono dan Azwar rancangan ini bersifat

\footnotetext{
25 Sugiyono, Metode Penelitian Kuantitatif, Kualitatif dan $R \mathcal{E}$ D, 158-61; lihat juga Arikunto, Metodologi Penelitian.

26 K. Aquino, A. Reed, S. Thau, dan D. Freeman, “A Grotesque and Dark Beauty: How Moral Identity and Mechanisms of Moral Disengagement Influence Cognitive and Emotional Reactions to War," Journal of Experimental Social Psychology 43, no. 3 (2007): 385-92.
} 
betul-betul eksperimen karena sampel yang digunakan untuk eksperimen maupun sebagai kelompok kontrol diambil secara acak dari populasi tertentu. ${ }^{27}$ Desain yang digunakan dalam rancangan penelitian ini adalah Pretest-Posttest Control Group Design:

\section{$\mathrm{Ge}(\mathrm{R}) \mathrm{O}_{1} \times \mathrm{O}_{2}$}

$\mathrm{Gk}(\mathrm{R}) \quad \mathrm{O}_{3} \quad \mathrm{O}_{4}$

Ge (R) adalah grup atau kelompok eksperimen. Gk (R) adalah grup atau kelompok kontrol. $\mathrm{R}$ adalah peserta didik dalam kelompok dipilih secara acak dengan teknik Simple Random Sampling. O adalah pengukuran terhadap variabel dependen. $\mathrm{X}$ adalah pemberian perlakuan. $\mathrm{O}_{1}$ dan $\mathrm{O}_{3}$ diobservasi dengan pretest untuk mengetahui kemampuan pengambilan keputusan etis awalnya. Yang diharapkan kemampuan pengambilan keputusan etis awalnya tidak berbeda secara signifikan. $\mathrm{X}$ adalah intervensi pemahaman identitas moral. $\mathrm{O}_{2}$ adalah kemampuan pengambilan keputusan etis yang telah dikenai perlakuan $\mathrm{X}$ dan $\mathrm{O}_{4}$ adalah kemampuan pengambilan keputusan etis yang tidak dikenai perlakuan $X$.

Desain penelitian demikian membutuhkan dua kali analisis. Analisis yang pertama adalah menguji perbedaan kemampuan awal antara

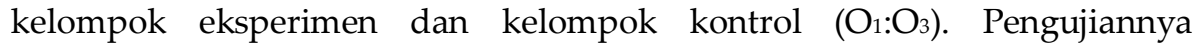
menggunakan $\chi^{2}$ untuk satu variabel. Hasil yang diharapkan tidak terdapat perbedaan yang signifikan antara kemampuan awal kelompok kontrol dan kelompok eksperimen, yaitu antara $\mathrm{O}_{1}$ dan $\mathrm{O}_{3}$. Analisis yang kedua adalah untuk menguji hipotesa yang diajukan (hipotesa nihil, $\mathrm{H}_{0}$ ). Dalam hal ini hipotesa yang diajukan adalah tidak ada korelasi positif antara pemahaman

\footnotetext{
27 Sugiyono, Metode Penelitian Kuantitatif, Kualitatif dan R E D, 84-85 dan Saifuddin Azwar,
} Metode Penelitian, cetakan ke-7 (Yogyakarta: Pustaka Belajar, 2007), 117-22. 
identitas moral dengan pengambilan keputusan etis. Teknik statistik yang digunakan untuk menguji hipotesa tersebut adalah teknik t-test untuk dua sampel yang terkait. Yang diuji adalah perbedaan antara $\mathrm{O}_{2}$ dan $\mathrm{O}_{4}$. Berdasarkan skala Likert yang digunakan, kalau terdapat perbedaan di mana nilai t-test $\mathrm{O}_{2}$ lebih kecil daripada $\mathrm{O}_{4}$ maka terdapat korelasi positif antara pemahaman identitas moral dengan kemampuan pengambilan keputusan etis. Karena data yang akan dianalisis tidaklah banyak, di bawah 100, maka uji statistiknya tidak akan menggunakan paket perangkat lunak (program) komputer untuk analisisnya melainkan menggunakan kalkulator tangan biasa.

\section{Kontribusi Penelitian}

Meskipun eksperimen-eksperimen tentang identitas moral telah dikembangkan untuk menemukan pengaruhnya terhadap pengambilan keputusan di tempat kerja dan di dalam kelas etika bisnis, ${ }^{28}$ masih sedikit penelitian yang telah dilakukan untuk menyelidiki implikasi pemahaman identitas moral bagi pembelajaran dan pengajaran pengambilan keputusan etis di dalam sebuah proses pendidikan agama. Artikel ini merupakan salah satu studi empiris untuk menunjukkan bahwa kegiatan pembelajaran yang tidak mengabaikan identitas moral memberikan dampak positif menolong para peserta didik agama untuk mengambil keputusan etis dengan lebih baik.

\footnotetext{
28 Jun Gu dan Cristina Neesham, “Moral Identity as Leverage Point in Teaching Business Ethics," Journal of Business Ethics 124, no. 3 (2014): 527-36; C. D. Cameron dan B. K. Payne, "The Cost of Callousness: Regulating Compassion Influences the Moral Self-concept," Psychological Science 23, no. 3 (2012): 225-29; S. T. Hannah, B. J. Avolio dan D. R. May, "Moral Maturation and Moral Conation: A Capacity Approach to Explaining Moral Thought and Action," Academy of Management Review 36, no. 4 (2011): 663-85; B. McFerran, K. Aquino, dan M. Duffy, "How Personality and Moral Identity Relate to Individuals' Ethical Ideology," Business Ethics Quarterly 20, no. 1 (2010): 35-56, dan A. Reed, II, K. Aquino, dan E. Levy, “Moral Identity and Judgments of Charitable Behaviors," Journal of Marketing 71, no. 1 (2007): 178-93.
} 


\section{Laporan Penelitian}

Blasi berpendapat bahwa pemahaman identitas moral membutuhkan waktu yang lama untuk dapat berakar dan berkembang dalam diri seseorang. ${ }^{29}$ Walaupun demikian, ada pula penelitian yang menunjukkan bahwa identitas moral seseorang dapat diperkuat dalam jangka waktu yang pendek. Secara khusus, Aquino dan kawan-kawan menyediakan sebuah perangkat penelitian yang telah teruji untuk secara sementara waktu memperkuat pemahaman seseorang tentang identitas moralnya. ${ }^{30}$ Artikel ini menggunakan perangkat tersebut dalam melakukan penelitian yang dilakukan.

Perangkat penelitian tersebut dikembangkan sesuai konteks penelitian yang dilakukan melalui sejumlah tugas refleksi yang didistribusikan kepada para peserta didik selama satu semester. Tugastugas tersebut bertujuan untuk membuat peserta didik berulang kali melakukan refleksi diri tentang pemahaman identitas moral yang mereka miliki. Setelah proses ini selesai, dilanjutkan dengan eksperimen yang menguji dampak dari tugas-tugas refleksi tersebut terhadap kemampuan para peserta didik dalam pengambilan keputusan etis mereka dibandingkan dengan para peserta didik yang tidak mendapatkan perlakuan yang sama. Sampel, prosedur, materi dan hasil dari penelitian akan dirinci di bawah ini.

\section{Tahap Penelitian}

Para peserta didik dengan jumlah keseluruhan 84 orang diambil secara acak dari dua kelas agama Kristen di sebuah sekolah teknik di Surabaya. Ada 12 kali tatap muka dalam kelas-kelas tersebut selama satu semester. Sebuah kelas dengan jumlah 40 orang (Kelas A) akan mengalami

\footnotetext{
29 A. Blasi, "The Development of Identity: Some Implications for Moral Functioning," dalam

G. G. Noam dan T. E. Wren (Eds.), The Moral Self(Cambridge, MA: MIT, 1993), 99-122.

30 K. Aquino, A. Reed, S. Thau, dan D. Freeman, "A Grotesque and Dark Beauty."
} 
perlakukan tugas-tugas reflektif pemahaman identitas moral sedangkan kelas yang lain dengan jumlah 44 orang (Kelas B) tidak.

Salah satu faktor yang dapat menodai eksperimen dalam suatu penelitian adalah proses pengamatan yang disadari oleh mereka yang menjalani eksperimen. Penelitian Melissa Bateson menunjukkan bahwa perilaku manusia dapat berubah ketika menyadari bahwa mereka berada di bawah pengamatan. ${ }^{31}$ Karena itu, para peserta didik tidak mendapatkan pemberitahuan bahwa di dalam proses pembelajaran kelas agama Kristen yang mereka ikuti selama satu semester tersebut berlangsung juga suatu eksperimen.

Melalui silabus yang dijelaskan di pertemuan tatap muka pertama, mereka hanya dikondisikan untuk menyadari bahwa segala yang mereka lakukan di kelas, termasuk tugas-tugas refleksi dan pertanyaan-pertanyaan angket, adalah bagian dari penilaian partisipasi dan kehadiran mereka. Ketika peserta didik tidak menyadari bahwa mereka sebenarnya sedang melakukan sebuah eksperimen, diharapkan eksperimen dapat berlangsung dengan lebih objektif.

Pretest dilakukan untuk menilai apakah kedua kelas memiliki perbedaan signifikan terkait dengan kemampuan pengambilan keputusan etis mereka sebelum dikenai perlakukan eksperimen. Karena itu, di pertemuan tatap muka pertama mereka semua menyelesaikan sebuah skenario keputusan moral yang pernah digunakan oleh Butterfield dan kawan-kawan. ${ }^{32}$ Melalui skenario ini para peserta didik di kedua kelas tersebut memainkan peran seorang manajer dan harus memutuskan apakah mereka akan atau tidak akan mempekerjakan seorang mantan karyawan

\footnotetext{
31 Melissa Bateson, Daniel Nettle, dan Gilbert Roberts, “Cues of Being Watched Enhance Cooperation in a Real-world Setting," Biology Letters 2, no. 3 (2006): 412-14.

32 K. D. Butterfield, L. K. Trevin o, dan G.R. Weaver, "Moral Awareness in Business Organizations: Influences of Issue-related and Social Context Factors," Human Relations 53, no. 7 (2000): 981-1018.
} 
perusahaan saingan demi memperoleh informasi rahasia darinya sehingga menguntungkan perusahaan di mana manajer itu bekerja.

Selanjutnya selama satu semester, para peserta didik di kelas A dan kelas B masing-masing menjalani perlakuan eksperimen di mana di kelas A mereka melakukan tugas refleksi diri terkait dengan sebuah sifat moral, sedangkan di kelas B tidak terkait dengan sebuah sifat moral. Tugas-tugas ini diulangi selama 9 pertemuan, menggunakan sifat moral atau sifat bukan moral yang berbeda-beda. Setelah 9 pertemuan itu selesai para peserta didik kelas A dan B memberi respons terhadap sebuah skala Likert yang telah diuji oleh Detert dan kawan-kawan untuk mengukur kemampuan pengambilan keputusan etis mereka. ${ }^{33}$

\section{Materi Penelitian}

Dalam skenario yang dikembangkan oleh Butterfield dan kawankawan, $^{34}$ para peserta didik mengambil peran seorang manajer yang diperhadapkan dengan pengambilan keputusan etis terkait dengan mempekerjakan seorang karyawan baru. Secara khusus, mereka ditanya untuk memilih satu dari dua kandidat yang secara kualitas tidak berbeda. Seorang kandidat, walaupun demikian, telah memiliki pengalaman kerja dengan kompetitor dari perusahaan yang ada dan telah menyatakan keinginan untuk membagikan informasi rahasia yang penting dari tempat asal di mana ia pernah bekerja jika ia diterima perusahaan ini. Telah dijelaskan di skenario bahwa informasi ini dapat meningkatkan pangsa pasar perusahaan tersebut sekaligus dapat membuat kompetitor menjadi

\footnotetext{
33 J. R. Detert, L. K. Trevin o, dan V.L. Sweitzer, "Moral Disengagement in Ethical Decision Making: A Study of Antecedents and Outcomes," Journal of Applied Psychology 93, no. 2 (2008): 374-91.

34 K. D. Butterfield, L. K. Trevin o, dan G. R. Weaver, “Moral Awareness in Business Organizations."
} 
kehilangan bisnisnya. Di dalam skenario ini juga diindikasikan bahwa mempekerjakan mantan karyawan kompetitor untuk memperoleh informasi rahasia mungkin salah secara etis. Jawaban dari para peserta didik didata untuk menghasilkan suatu nilai kemampuan mengambil keputusan etis $(0=$ mempekerjakan mantan karyawan kompetitor, 1 = mempekerjakan kandidat yang lain).

Tugas-tugas refleksi identitas moral yang dipakai adalah berdasarkan perangkat penilitian yang dikembangkan oleh Aquino dan kawan-kawan. ${ }^{35}$ Selama 9 minggu pertemuan para peserta didik dalam kelas A diminta untuk menyelesaikan tugas-tugas refleksi diri setiap minggunya, di mana mereka melakukan refleksi selama 60 detik tentang diri mereka sendiri terkait dengan sebuah sifat moral dan lalu melaporkan hasil refleksi itu dengan cara menulis dalam sebuah paragraf singkat tentang siapa mereka menggunakan sifat moral tersebut sebanyak lima kali. Sifat-sifat moral yang mereka tulis selama 9 pertemuan itu adalah (satu untuk satu pertemuan dalam urutan kronologis): "mempedulikan", "berbelas-kasihan”, “adil", "bersahabat", "dermawan”, "suka menolong", "bekerja-keras", "jujur", dan "baik". Para peserta didik dalam kelas B diminta juga untuk melengkapi sejumlah tugas refleksi yang serupa, hanya saja tidak terkait dengan sifat moral: "tiada beban", "rukun", "menyenangkan", "riang”, "bahagia", "tidak-berbahaya", "berpikiran-terbuka", "terhormat”, dan "santun".

Setelah selesai dengan tugas-tugas refleksi diri itu, para peserta didik mengerjakan 8 soal skala etis yang diadaptasi dari perangkat yang dikembangkan dan teruji oleh Detert dan kawan-kawan yang menggunakan skala Likert 7 poin $(1$ = sangat tidak mungkin sekali dilakukan, 7 = sangat mungkin sekali dilakukan). ${ }^{36}$ Sebuah contoh soal adalah "Anda ditugaskan

\footnotetext{
35 K. Aquino, A. Reed, S. Thau, dan D. Freeman, "A Grotesque and Dark Beauty."

36 J. R. Detert, L. K. Trevin o, dan V. L. Sweitzer, “Moral Disengagement in Ethical Decision Making."
} 
dalam sebuah kelompok di salah satu kelas yang Anda ikuti. Kelompok anda menunggu sampai dekat batas waktu pengumpulan untuk mulai mengerjakan tugas yang diberikan. Beberapa anggota kelompok lalu mengusulkan untuk langsung saja menggunakan hasil kelompok yang telah dikerjakan oleh angkatan-angkatan sebelumnya sehingga tidak perlu kerja keras lagi. Anda setuju dan mengikuti rencana ini." Jawaban terhadap soalsoal itu menentukan nilai kemampuan pengambilan keputusan etis, dengan nilai yang lebih rendah mewakili kemampuan pengambilan keputusan etis yang lebih baik

\section{Hasil Penelitian}

Yang pertama-tama dikaji adalah perbandingan antara para peserta didik di kedua kelas berdasarkan tanggapan mereka terhadap skenario keputusan etis (yaitu keputusan untuk mempekerjakan seorang karyawan baru). Hipotesis nihil $\left(\mathrm{H}_{0}\right)$ dalam penelitian ini adalah tidak ada korelasi positif antara pemahaman identitas moral dengan pengambilan keputusan etis. Hasilnya adalah seperti yang diperkirakan bahwa hipotesis nihil tidak disangkal melalui pretest ini. Para peserta didik yang nantinya dikondisikan untuk menerima perlakukan refleksi identitas moral (Kelas A) memberikan nilai keputusan etis yang tidak berbeda jauh dengan para peserta didik yang nantinya dikondisikan untuk tidak menerima perlakukan serupa (Kelas B). Nilai yang dihasilkan oleh Kelas A adalah 70\% memilih untuk bersikap etis dalam skenario keputusan etis dengan tidak mempekerjakan mantan karyawan kompetitor. Sedangkan nilai yang dihasilkan oleh Kelas B tidak berbeda jauh dengan memberikan jawaban yang sama dengan Kelas A yaitu $72.7 \%\left(\chi^{2}=6.87, p=0.99\right)$. Hasil tersebut menunjukkan bahwa para peserta didik dalam kedua kelas tersebut memiliki kemampuan tidak berbeda secara signifikan dalam pengambilan keputusan etis mereka sebelum menerima perlakukan yang direncanakan. 
Setelah mengalami 9 kali perlakuan, barulah uji terhadap hipotesis yang diajukan dilakukan dengan sepenuhnya. Hasilnya adalah nilai t-test kelas $\mathrm{A}(\mathrm{M}=3.57, \mathrm{SD}=1.06, t(39)=-2.47, p=0.01)<($ lebih kecil) daripada kelas $\mathrm{B}(\mathrm{M}=3.72, \mathrm{SD}=0.89, t(43)=-2.015, p=0.025)$. Ini mendemonstrasikan bahwa para peserta didik dalam kelas A, yang dikondisikan melakukan refleksi diri terkait dengan sifat-sifat moral, membuat keputusan etis yang lebih baik dibandingkan para peserta didik di kelas B, yang hanya melakukan refleksi diri tidak terkait dengan sifat-sifat moral. Hasil ini juga menunjukkan bahwa hipotesis nihil $\left(\mathrm{H}_{0}\right)$ yaitu tidak ada korelasi positif antara pemahaman identitas moral dengan pengambilan keputusan etis harus disangkal dan diganti dengan hipotesis alternatif $\left(\mathrm{H}_{\mathrm{a}}\right)$ yaitu terdapat korelasi positif antara pemahaman identitas moral dengan pengambilan keputusan etis. Analisis ini menyatakan bahwa para peserta didik dalam pendidikan agama Kristen dapat ditolong untuk mengambil keputusan etis dengan lebih baik melalui menumbuh-kembangkan dalam diri mereka pemahaman identitas moral.

\section{Implikasi Penelitian}

Artikel ini bertujuan untuk menjawab pertanyaan apakah menanamkan pemahaman identitas moral meningkatkan kemampuan peserta didik kelas agama Kristen dalam mengambil keputusan etis. Demi mencapai tujuan tersebut sebuah penelitian yang mencari korelasi positif antara pemahaman identitas moral dan pengambilan keputusan etis telah dikembangkan. Hasil yang didapat menunjukkan bahwa pemahaman identitas moral memang dapat meningkatkan kemampuan para peserta didik untuk mengambil keputusan etis dengan lebih baik. Karena itu, pendidikan agama seharusnya tidak mengabaikan soal identitas moral dalam proses pembelajaran yang dilakukan. Hal demikian memiliki dua implikasi praktis. 
Pertama, etika memegang peran yang penting dalam pendidikan agama karena diharapkan melaluinya setiap orang dapat menjadi lebih baik lagi secara moral. Karena secara empiris dapat dilihat bahwa melalui pengambilan keputusan etis seseorang semakin berperilaku lebih bermoral, ${ }^{37}$ penelitian yang dilaporkan artikel ini memberikan kontribusi dengan menunjukkan pentingnya pemahaman identitas moral dalam sebuah pendidikan agama. Hal ini tidak berarti bahwa pendidikan agama hanya boleh mengajarkan pemahaman identitas moral. Bukan demikian. Artikel ini tidak menafikan pentingnya pengajaran dan pemahaman aturanaturan agama yang harus dilakukan oleh para pengikutnya. Melainkan justru semakin melengkapi proses pembelajaran dalam pendidikan agama untuk menolong para peserta didik menjadi manusia yang lebih bermoral. Hal ini konsisten dengan keyakinan Maclagan bahwa pembelajaran yang menekankan aturan seharusnya dikombinasikan dengan pembelajaran yang berfokus pada "nilai-nilai pribadi, atau identitas moral" demi menjamin sebuah keseimbangan yang lebih baik di antara seorang individu, pengambilan keputusan yang kontekstual dan prinsip etis yang lebih objektif dan dapat diterima oleh banyak orang. ${ }^{38}$

Kedua, cara pembelajaran yang diulang-ulang melalui tugas-tugas refleksi diri mendukung tujuan pembentukan kebiasaan yang baik. Pembentukan kebiasaan yang baik itu seringkali terjadi melalui proses yang dilakukan berulang-ulang. ${ }^{39}$ Dalam dunia bisnis, pembentukan kebiasaan

\footnotetext{
37 R. R. Sims dan E. L. Felton, Jr., “Designing and Delivering Business Ethics Teaching and Learning," Journal of Business Ethics 63, no. 3 (2006): 297-312.

38 P. Maclagan, "Conflicting Obligations, Moral Dilemmas and the Development of Judgement through Business Ethics Education," Business Ethics: A European Review 21, no. 2 (2012): 183-97.

39 Lihat misalnya penelitan-penelitian yang telah dilakukan dalam dunia bisnis oleh B. A. Ritter, "Can Business Ethics be Trained? A Study of the Ethical Decision-making Process in Business Students," Journal of Business Ethics 68, no. 2 (2006): 153-64 dan A. R. Oddo, "A Framework for Teaching Business Ethics," Journal of Business Ethics 16, no. 3 (1997): 293-97.
} 
baik demikian telah menjadi suatu syarat mendasar bagi pembentukan karakter seseorang pebisnis yang bermoral.40 Tentunya sudah menjadi rahasia umum bahwa seorang yang beragama diharapkan juga sebagai seorang yang berkarakter baik. Dan untuk memiliki karakter yang baik seseorang perlu membangun kebiasan yang baik, dalam hal ini, kebiasaan untuk mengambil keputusan etis sesuai dengan identitas moralnya.

\section{Keterbatasan Penelitian}

Penelitian dalam artikel ini dilakukan secara terbatas baik itu secara lokal dan temporal. Perlu diadakan penelitan lebih lanjut di tempat yang berbeda, dan dalam jangka waktu lebih lama untuk dapat mempertajam teori yang dikembangkan melalui penelitian ini. Secara khusus, pengukuran kemampuan pengambilan keputusan etis para peserta didik tersebut tidak berlanjut setelah semester yang ada berakhir. Karena itu pengujian ulang dampak pemahaman identitas moral terhadap mereka setelah jangka waktu yang lebih lama tidak dapat dilakukan. Keterbatasan demikian patut menjadi perhatian karena adanya keraguan yang diungkapkan oleh beberapa peneliti berkaitan dengan dampak berkelanjutan dari pembelajaran dengan cara seperti ini.41 Walaupun demikian, Blasi berpendapat sebaliknya bahwa pembelajaran yang menanamkan pemahaman identitas moral akan memiliki dampak dalam waktu yang

\footnotetext{
40 M. Crossan, D. Mazutis, dan G. Seijts, "In Search of Virtue: The Role of Virtues, Values and Character Strengths in Ethical Decision Making," Journal of Business Ethics 113, no. 4 (2012): 56781; E. M. Hartman, "The Role of Character in Business Ethics," Business Ethics Quarterly 8, no. 3 (2009): 547-59; dan T. M. Jones, W. Felps, dan G. A. Bigley, "Ethical Theory and Stakeholderrelated Decisions: The Role of Stakeholder Culture," Academy of Management Review 32, no. 1 (2007): 137-55.

41 Misalnya C. D. Schmidt, K. M. Davidson, dan C. Adkins, “Applying What Works: A Case for Deliberate Psychological Education in Undergraduate Business Ethics," Journal of Education for Business 88, no. 3 (2013): 127-35 dan A. Etzioni, "When It Comes to Ethics, B-schools Get an F," The Washington Post (2002), 4, B4.
} 
tidak singkat karena proses itu memperkuat konsep diri moral dalam diri peserta didik yang akan secara konsisten mempengaruhi tingkah laku mereka. ${ }^{42}$ Mungkin para peneliti di masa mendatang dapat menguji pendapat ini dengan studi yang lebih mendalam dan lebih lama di mana pengambilan keputusan etis para peserta didik akan dievaluasi secara berulang dalam jangka waktu yang panjang, seperti dari 1 tahun sampai 5 tahun.

\section{Kesimpulan}

Untuk menghindari penekanan berlebihan pada emosi, pengetahuan tentang aturan moral ataupun lingkungan dalam proses menjadikan manusia beragama memiliki karakter yang lebih baik lagi secara moral, pendidikan agama sepatutnya memperhatikan juga identitas moral dalam proses pembelajaran yang dilakukan. Jika hal ini terjadi, maka seperti yang penelitian dalam artikel ini telah demonstrasikan, para peserta didik dapat meningkatkan kemampuan mereka dalam mengambil keputusan etis. Dengan demikian, mereka dapat diharapkan untuk menjadi manusia beragama yang semakin berkarakter baik secara moral.

\footnotetext{
42 A. Blasi, “Moral Character: A Psychological Approach," bandingkan juga hal serupa yang telah diungkapkannya dalam "The Development of Identity: Some Implications for Moral Functioning."
} 